\title{
OPPORTUNITIES AND CHALLENGES FOR DEVELOPING CAULERPA RACEMOSA AS FUNCTIONAL FOODS
}

\author{
Diini Fithriani \\ Research Centre and Development For Product Processing and Biotechnology \\ Marine and Fisheries Affair \\ Email : diini_fithriani@yahoo.com
}

\begin{abstract}
The higher public awareness of the health in community would made the view of some people for food has shifted, not only as relieving hunger, but also can provide a real impact for health. This phenomenon has resulted a term what is called functional food'. Functional food is defined as food which contain active compounds that play a role in increasing endurance, minimize the risk of attack of certain diseases and to provide maximum health benefits. One of marine resource that have a potency to develop as functional foods is Caulerpa racemosa. Caulerpa racemosa is one of green seaweed that grows naturally in the waters of Indonesia. Caulerpa racemosa found growing on coral substrate or a substrate of sand-rubble. Caulerpa racemosa is edible or can be consumed by humans. Caulerpa racemosa from Indonesia contains high insoluble dietary fiber. Insoluble dietary fiber contains cellulose and hemicellulose, who plays an important role in preventing constipation, colitis and hemmoroid. In other hand Caulerpa racemosa can also produce secondary metabolites, including antioxidants. Antioxidants are substances that are capable of slowing or preventing the oxidation processes that are beneficial to health.
\end{abstract}

Keywords: antioxidant, Caulerpa racemosa, fiber, functional food, health

\section{INTRODUCTION}

Growing understanding of the relationship between diet, specific food ingredients and health is leading to new insights into the effect of food components on physiological function and health. This awarness has moved consumers to become more health-conscious, driving a trend towards healthy and nutritious foods with additional health promoting functions, such as functional foods. Although there is no officially accepted definition of functional foods, acording to Grajek et al.(2005) functional food is a part of human diet and is demonstrated to provide health benefits and to decrease the risk of chronic diseases beyond those provided by adequate nutrition. The functional foods include: (i) usual foods with naturally occurring bioactive substances (e.g., dietary fibre), (ii) foods supplemented with bioactive substances (e.g., probiotics, antioxidants), and (iii) derived food ingredients introduced to conventional foods (e.g., prebiotics). Functional food should have a novel prospective, rather than a food product. It should also be mentioned that functional foods are not medicines such as pills or capsules but are consumed as part of a normal daily diet, functional food is a part of human diet and is demonstrated to provide health benefits and to decrease the risk of chronic diseases beyond those provided by adequate nutrition.

According to the Agency for Food and Drug Administration (2001), the definition of functional food is a food that as natural or has been through the process, containing one or 
more compounds that are based on scientific studies have specific physiological functions that are beneficial to health.

Caulerpa racemosa is one of many seaweed species that growth naturally in Indonesian waters. It is found in coral reef area attributed to the coral substrate or found in sand-rubble substrate or sometime found in rope that used to cultivate Kapapycus alvarezii. Caulerpa racemosa in Indonesia are traditionally utilized as food in the form of fresh vegetable or lalap, but the consumers is still limited to fishermen family or coastal area society (Fithriani 2009). Caulerpa racemosa is an edible and treasure house of novel healthy food ingredients and biologically active compounds, this make this organismcould be considered as source of functional food.

This review focuses on Caulerpa racemosa as functional food. Moreover, it highlights edible property and active compound that found in this organism and outlines formulation of functional food. Furthermore, challenges that will face on developing Caulerpa racemosa as fuctional food will be briefly discussed.

\section{INTRODUCTION TO CAULERPA RACEMOSA}

Caulerpa racemosa (Caulerpales, Chlorophyta) (Figure $1 \& 2$ ) is widely distributed in tropical to warm-temperate region (Verlaque 2003).

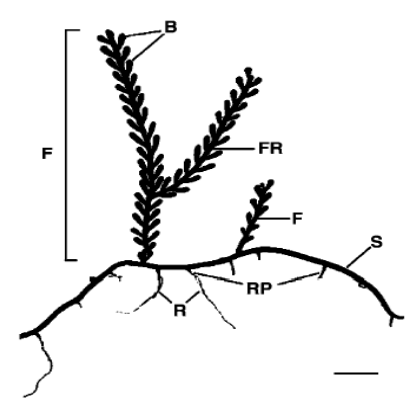

Figure 1. Caulerpa racemosa var. cylindracea: different thallus (Capiomont 2005)

$F=$ frond (primary frond); $F R=$ frond ramification (secondary frond) ; $B=$ branchlets (also named ramuli); $S=$ stolon; $\mathrm{RP}=$ rhizoidal pillars (conical ramifications of the stolon bearing numerous thin rhizoids; $R=$ Rhizoids (aglutinated)

\section{Environmental tolerance}

Growth of Caulerpa racemosa has been shown to increase as density increases, but to a lesser degree than with Caulerpa taxifolia (Piazzi et al. 2002). In laboratory conditions, Caulerpa racemosa stopped growing when salinitywas reduced to $20 \mathrm{ppt}$, but did not die after twenty days (Carruthers et al. 1993). Caulerpa racemosa can withstand short-term exposure to salinity as low as $20 \mathrm{ppt}$, and may be able to begin growth if salinity levels rise after that exposure (Carruthers et al. 1993). 


\section{Reproduction of Caulerpa racemosa}

Caulerpa racemosa is known to reproduce both sexually and asexually by random fragmentation (Renoncourt 2002 in Capiomont 2005). In the same environment Caulerpa racemosa has the ability to spread faster than Caulerpa taxifolia (Piazzi et al. 2001). Caulerpa racemosa has also been observed to produce vegetative propagules which may explain the disappearance of Caulerpa racemosa meadows during the winter and their reappearance by the end of spring (Renoncourt 2002 in Capiomont 2005).

\section{Defense mechanisms}

Some specimens of Caulerpa racemosa have been found to contain thedefensive compound that called caulerpenyne (Cimino 1998). In Discovery Bay, Jamaica research suggests that Caulerpa racemosa is resistant to fish grazing by dominant reef fish such as parrot fish (Scaridae), but can not deter when grazing by the long-spined urchin (Diadema antillarum) (Morrison 1988).

\section{Natural controls}

The long-spined urchin (Diadema antillarum), which is endemic to the Caribbean, readily consumes Caulerpa racemosa (Morrison 1988), although it is not a preferred food (Williams and Grosholz 2002). The Mediterranean herbivorous fish, Boops boops and Sarpa salpa, essentially grazed on Caulerpa racemosa in late summer and early autumn (Ruiton et al. 2005). A sacoglossan mollusk (Lobiger serradifalci) has also been observed feeding on wild populations of Caulerpa racemosa off the coast of Venezuela (Cimino 1998).

\section{OPPORTUNITY OF CAULERPA RACEMOSA AS SOURCE OF FUNCTIONAL FOOD}

\section{Edible property}

In Indonesia Caulerpa racemosa has been used as fresh vegetables or salad, a unique flavor much preferred, but consumers in Indonesia are still limited to the families of fishermen or coastal communities. This is very different from the situation in other countries such as Japan, Fiii, Philippines or Thailand. In Thailand,Caulerpa racemosa is commonly found in the Phuket market, where $10-20 \mathrm{~kg}$ sold each day, to be used as a spicy sauce. Caulerpa racemosa that have edible characteristic make people are easier to get the health benefit without many process. Edible marine algae, sometimes referred as seaweeds, have attracted a special interest as good sources of nutrients and one particular interesting feature is their richness in sulfated polysaccharides (SPs), the uses of which span from food, cosmetic and pharmaceutical industries to microbiology and biotechnology (Ren 1997 in Wijesekara et al. 2011). 


\section{Nutrient content of Caulerpa racemosa}

Table 1. Nutrient composition of Caulerpa racemosa

\begin{tabular}{ll}
\hline Nutrients (\% DW) & \multicolumn{2}{c}{ Value } \\
\hline Moisture (\%) & $91.53 \pm 8.80$ \\
Ash & $24.20 \pm 2.20$ \\
Protein & $12.88 \pm 1.17$ \\
Carbohydrate & $48.95 \pm 2.06$ \\
Lipid & $2.6 \pm 0.20$ \\
Total Carbon & $38.03 \pm 1.84$ \\
Total Nitrogen & $2.06 \pm 0.19$ \\
C/N & $18.45 \pm 1.28$ \\
Energy (kJ g-1DW) & $10.91 \pm 1.74$ \\
\hline Source $:$ Kumar et al. (2011) &
\end{tabular}

According to research that conducted by Kumar et al. (2011) The energy values obtained for Caulerpa racemosa contributed by carbohydrates and proteins because the total lipid content in Caulerpas racemosa were low $(2,06 \%$ DW). Therefore, this algae is suitable for diet foods intended to reduce obesity. Caulerpa racemosa from Indonesia have higher insoluble dietary fiber than Caulerpa racemosa from Japan (Santoso 2002). Insoluble dietary fiber containing cellulose and hemicellulose which plays an important role in preventing constipation, colitis and haemmorhoid (MacArtain et al 2007 in Mohammed et al. 2011).

Table 2. Mineral composition of Caulerpa racemosa compare to RDA

\begin{tabular}{cccccccc} 
& $\mathrm{Na}$ & $\mathrm{K}$ & $\mathrm{Ca}$ & $\mathrm{Mg}$ & $\mathrm{Fe}$ & $\mathrm{Cu}$ & $\mathrm{Zn}$ \\
\hline C.racemosa (mg 10 g-1DW) & 1064 & 503 & 476 & 161 & 2.97 & 0.06 & 0.68 \\
*RDA (mg 100 g-1DW) & $171)$ & $(25)$ & $(60)$ & $(43)$ & $(21)$ & $(6)$ & $(7)$ \\
\hline
\end{tabular}

Source : Kumar et al. 2011

Values indicated in () represent the approximate \% of RDA values provided by $10 \mathrm{~g}$ dry C.racemosa

*(RDA) is Recommended daily allowance of minerals content for adults male (EU Health and Cosumer DirectorateGeneral)

According to table 2 Caulerpa racemosa rich of mineral content. $10 \mathrm{~g}$ Caulerpa racemosa powder provides approximately $60 \%$ of recommended daily allowance (RDA) of calcium and $43 \%$ of magnesium for an adult male. Calcium which functions as a cofactor for many extracellular enzymes and well known for strengthening the bones, teeth structure and muscle contraction (Kumar et al. 2011). Zn and Cu are essential cofactor for enzyme systems(cytochrome C-oxidase), stabilises membrane, hormones and nucleic acids (Norziah and Ching 2000). The higher content of Fe in Caulerpa racemosa could be due to the availability of more intercellular space (Misheer et al. 2006).

Novaczek (2001) in Chew et al. (2008) states that Caulerpa racemosa rich in folic acid, ascorbic acid, vitamin A and B1 (thiamin). In addition, Caulerpa used in traditional medicine to reduce blood pressure and to treat rheumatism (Novaczek 2001; Prud'homme van Reine and Trono 2001 in Chew 2008). 


\section{Antioxidant activity}

Antioxidants are compounds that inhibit or delay the oxidation of other molecules by inhibiting the initiation or propagation of oxidising chain reactions. Studies have shown that free radicals present in the human organism cause oxidative damage to different molecules, such as lipids, proteins and nucleic acids and thus are involved in the initiation phase of some degenerative diseases. With that studies the role of antioxidants has drawn much attention as a candidate to combat certain diseases and prevent the aging process (Slater 1991 in Yee et al. 2007). The content of total phenols and antioxidant activity varies with species. But in general the green seaweed (Caulerpa spp.) had the highest free radical scavengers property followed green seaweed (Sargassum polycystum), and then the red seaweed (Eucheuma cottonii, Eucheuma spinosum and Halymenia durvillaei), or brown seaweed (Dictyota dichotoma and Padina sp.).

In research by Fithriani (2009) known that the result of tested Caulerpa racemosa in different treatment (fresh and dry) and different solvents were known that characteristics of antioxidants Caulerpa racemosa dominated by antioxidants which are semi-polar, this is supported by research which the ethyl acetate extract has the highest total phenol content than methanol and hexane extract. While the test antioxidant activity with DPPH method showed that the ethyl acetate extract of fresh samples had the best antioxidant activity. From the results of a study, the antioxidant activity of seaweed Caulerpa racemosa in the Hurun Bay ranging of $10.94-23.68 \mathrm{mg} A A E / 100 \mathrm{~g}$. Santoso (2003) mentions that the polyphenol components contained in Caulerpa racemosa is katekol. Acording to Munifah (2008) active compound of free radical scavengers carotenoid fraction of fesh Caulerpa racemosa has $31.82 \%$ percent inhibition. The high content of carotenoid in Caulerpa racemosa could make it as an alternative antioxidant for scavenging the reactiveoxygen species (Kumar et al. 2011).

\section{Secondary plant metabolit (Caulerpenyne)}

Secondary plant metabolites, including enzymes and proteins, are produced by plants to regulate physiology and patterns of growth (Daniel et al. 1999 in Benbrook 2005). Some could help plants deal with environmental extremes, deter pest attacks, orrespond to damage caused when insects or plant pathogens reach damaging levels. Some play a role in repairing injured leaf or fruit tissue through the formation ofpigments. There are likely far more than 50,000 secondary plant metabolites andsome 4,000 flavonoids (Daniel et al. 1999 in Benbrook 2005).

Recently, the genus Caulerpa has attracted the attention of researchers due to its important secondary metabolite caulerpenyne (CYN) that is reported to exhibit the antineoplastic,antibacterial and antiproliferative activities (Barbier et al. 2001). The present study shows the antiproliferative effect of Caulerpa racemosa extract and newly attributed apoptotic effects of this extract. Compared to other alkylating anti cancer drugs, CPN and also Caulerpa racemosa var.cylindracea extract might be considered an alternative native 
source of antitumor drugs. It is worth while to note that the IC50 values of Caulerpenyne on both SHSY5Y and Kelly cell lines were very close to etoposide the CPN Therefore, CPN could be applied with etoposide in chemotherapy (Cavas et al. 2006).

\section{FUNCTIONAL FOOD FORMULATION FROM CAULERPA RACEMOSA}

The marine environment is a major reservoir of bioactive compounds that have potential to be applied in several phases of food processing, storage and fortification (Rasmussen and Morrissey 2007). Functional food based on Caulerpa racemosa could be served in the forms of health beverages, sauce, juice, fresh salad, pickle, added to meat product to give fiberetc. Utilization of Caulerpa racemosa in the form of fresh salad still possible because according to Siregar (2002) fruit and vegetables that consumed fresh is the simplest form of a functional food. In view of the industry, a popular form of functional food is beverages, because the beverages relatively easy to formulate (Day 2009).

Functional foods have been developed in virtually all food categories. From a product point of view, the functional property can be included in numerous different ways as it can be seen in Table 3.

Table 3. Prominent types of functional food

\begin{tabular}{cll}
\hline Type of functional food & \multicolumn{1}{c}{ Definition } & \multicolumn{1}{c}{ Example } \\
\hline Fortified product & A food fortified with additional nutrients & $\begin{array}{l}\text { Fruit juices fortified } \\
\text { with vitamin C }\end{array}$ \\
\hline \multirow{2}{*}{ Enriched products } & $\begin{array}{l}\text { A food with added new nutrients or components } \\
\text { not normally found in a particular food }\end{array}$ & $\begin{array}{l}\text { Margarine with plant } \\
\text { sterol ester, probiotics, } \\
\text { prebiotics }\end{array}$ \\
\hline \multirow{3}{*}{ Altered products } & $\begin{array}{l}\text { A food from which a deleterious component has } \\
\text { been removed, reduced or replaced with another } \\
\text { substance with beneficial effects }\end{array}$ & $\begin{array}{l}\text { Fibers as fat releasers } \\
\text { in meat or ice cream } \\
\text { products }\end{array}$ \\
\hline \multirow{2}{*}{ Enhanced commodities } & $\begin{array}{l}\text { A food in which one of the components has been } \\
\text { naturally enhanced through special growing } \\
\text { conditions, new feed composition, genetic } \\
\text { manipulation, or otherwise }\end{array}$ & $\begin{array}{l}\text { Eggs with increased } \\
\text { omega-3 content } \\
\text { achieved by } \\
\text { altered chicken fee }\end{array}$ \\
& &
\end{tabular}

Source : Kotilainen et al. 2006 in Siro 2008

Caulerpa racemosa could added to enhance functional poperty in food. In formulation Caulerpa racemosa as functional food we must be concern to other ingredient. The other inggredient should not give bad effect to health. For the example using much sugar will decreace the function of healthy drink that used for obesity tratment.

In formulating functional food we must concern what consumer awarness and what consumer want, know what consumer concern for their health is a key of succesfull functional food. Caulerpa racemosa rich in mineral,vitamin, fiber and antioxidant. According to Bornkessel (2013) calcium and vitamin $C$ are in the high of consumer awarness, while antioxidant and dietary fibre are in the middle of consumer awarness (table 4). In its most recent research, the Tates \& Lyles company uncovered three fiber trend. First consumer comport with the taste of 
added fiber in products is increasing. Second Tate \& Lyles proprietary research revealed that $44 \%$ of consumers are actively read food labels specifically for fiber and $66 \%$ are interested in fibre for their children. Finaly Tate \& Lyles found that consumers are willing to pay an average of $5 \%$ more for products fortified with fiber (Crawford 2010).

Table 4. Consumer awareness related to functional food ingredient

\begin{tabular}{lllll}
\hline $\begin{array}{c}\text { Consumers' } \\
\text { Awareness }\end{array}$ & $\begin{array}{c}\text { Research } \\
\text { history }\end{array}$ & $\begin{array}{c}\text { Market } \\
\text { diffusion }\end{array}$ & $\begin{array}{c}\text { Application } \\
\text { breadth }\end{array}$ & $\begin{array}{c}\text { Examples from the } \\
\text { study at hand }\end{array}$ \\
\hline High & Long & High & Broad & $\begin{array}{l}\text { vitamin C, iodine, } \\
\text { calcium }\end{array}$ \\
\hline Middle & Middle & Middle & $\begin{array}{l}\text { Broad to } \\
\text { specialized } \\
\text { dietary fiber }\end{array}$ & $\begin{array}{l}\text { omega-3- } \\
\text { fatty acids, probiotics, } \\
\text { antioxidants, } \\
\text { phytosterols }\end{array}$ \\
& & & Specialized & glucosamine, $x y l i t o l$ \\
\hline Low & Short & Low & &
\end{tabular}

In Japan, several foods (soybean paste, potato chips, and noodles) with added chitosan are available as cholesterol-lowering functional foods (Borderias et al. 2005). According to Kadam and Prabhasankar (2010), more and constant efforts in research and design of novel functional foods based on marine functional ingredients are needed for reducing health problems through the diet. The added three edible seaweeds Wakame (Undaria pinnatifida), Nori (Porphyra umbilicalis) and Sea Spaghetti (Himanthalia elongata) supplied the meat samples with soluble polyphenolic compounds, which increased the antioxidant capacity of the systems. The polyphenol supply and antioxidant increase were greatest $(P<0.05)$ in the samples containing Sea Spaghetti (Himanthalia elongata) (Lopez 2009).

The attainment of functional foods involves two aspects: on the one hand, the selection and characterization of bioactive components in the food, the technological design and development of the food and the assessment of factors that modify its content/bioavailability, and on the other, the evaluation of the functional effect using in vitro and in vivo models that provide information on mechanisms of action, impact on the in vivo function-response, doseresponse relationshipand acute and chronic effects (Howlett 2008).

\section{CHALENGGES OF CAULERPA RACEMOSA AS SOURCE OF FUNCTIONAL FOOD}

Some of the problems in development of functional food from crops acording to Percival and Turner (2001), are :

1. Determination of identity and the harvesting of crops as raw materials of functional foods.

2. Standardization product, because herbs and plants that grown or cultivated in different location can produce different active compound.

According to Fithriani (2009) Caulerpa racemosa that harvested in different location in Teluk Hurun shown different antioxidant activity (Figure 2) and total phenol content (Figure 3). The main thing that distinguished between stations 1,2 and 3 was the medium where Caulerpa racemosa grown. Station 1 was located in the inner of Hurun Bay. The station was close to fish 
cultivation and shrimp ponds. Station 2 was the station located in the outer of Hurun Bay far from mainland. Like station 1, Station 3 was nearest to mainland and Caulerpa racemosa grown in Coral reefs that was damaged mainly by sedimentation and bomb fishing by the fishermen. According to water quality analysis, stations 1,2 and 3 classified as light polluted waters with the highest pollution levels were at station 3, followed by station 1 and station 2 . Higher pollution at station 3 because station 3 were closest to the mainland, so getting pressure from the highest ground. Any factor that difference between three station is presence of herbivore and the last factor that significantly different between stations was the light in which the highest light intensity obtained by the station 2, where the light at the tide reaches 843 lux.

Higher antioxidant activity at the station 2 is thought to be influenced by several factors i.e : (1) The higher light intensity in this region, where the correlation test results showed a strong positive correlation between the antioxidant activity and the light intensity $(r=0.94)$. ( 2) The turtle presence as herbivorous predators in station 2 more a lot than other station, The presence of herbivores affect the antioxidant is supported by a statement Mitchell (2006) factor before harvesting processes that affect antioxidants in plants are divided into 2 factor a. Endogenous factors i.e. genotif, maturity b. Eksogenous factors i.e. climate, sun exposure, stress pathogen, herbivore, the micro environment and agronomic practices. (3) The physical condition of Caulerpa racemosa in the station 2 is quite good than other station.

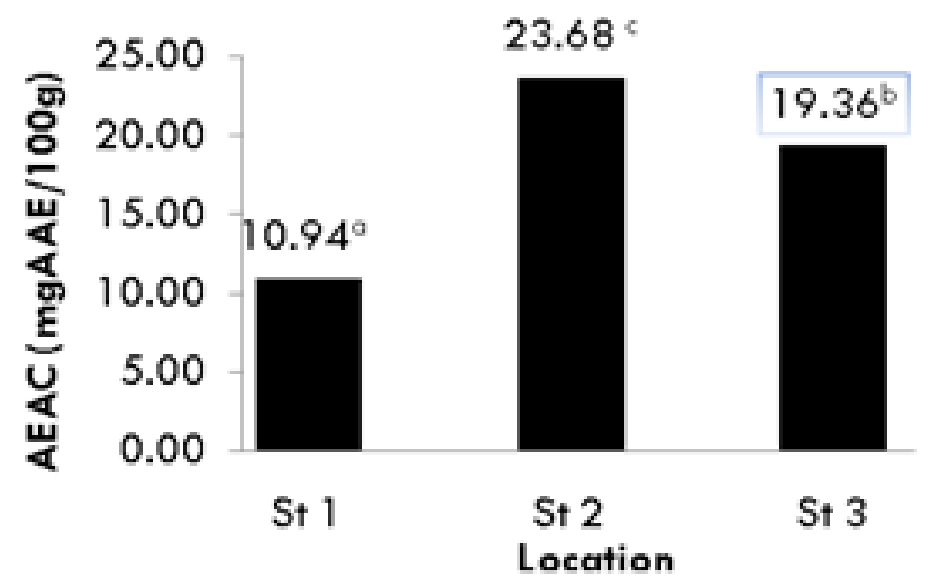

Figure 2. Antioxidant activity (AEAC) at three locations and antioxidant activity(IC 50) at three location. station 1 : close to fish cultivation and shrimp ponds, grown in rope, station 2 : far from mainland, grown in rope, station 3 : grown in damage coral reef area.Numbers on the histogram followed different letters $(a, b)$ indicates significantly different $(p<0.05)$.

The characteristics of marine environment such as various degrees of salinity, temperature, pressure, and illumination impart particular interest on compounds derived from marine organisms (Baerga and Ortiz 2009). 


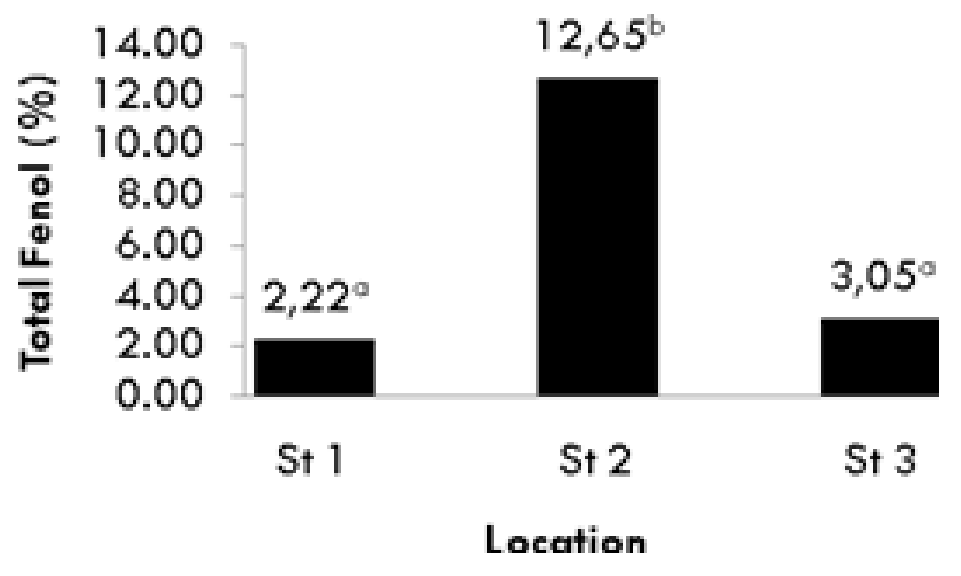

Figure 3. Total phenol content Caulerpa racemosa in three research sites. station 1 : close to fish cultivation and shrimp ponds, grown in rope, station 2 : far from mainland, grown in rope, station 3 : grown in damage coral reef area. Numbers on the histogram followed different letters $(a, b)$ indicates significantly different $(p<0.05)$.

According to Cavas and Yurdakoc (2005) the antioxidant status of Caulerpa racemosa is not strictly correlated with both solar radiation and seawater temperature; however, the growth of epiphytes on fronds might change antioxidant status.

The characteristics of marine environment such as various degrees of salinity, temperature, pressure, and illumination impart particular interest on compounds derived from marine organisms (Baerga and Ortiz 2009). According to Cavas and Yurdakoc (2005) the antioxidant status of Caulerpa racemosa is not strictly correlated with both solar radiation and seawater temperature; however, the growth of epiphytes on fronds might change antioxidant status.

\section{IMPACTS OF FOOD PROCESSING}

The way foods are processed, mixed together with other foods, cooked, preserved and prepared for final consumption can dramatically affect polyphenol antioxidant levels. In the near term, increasing the retention of antioxidants in foods as they are processed and prepared is likely to offer the greatest potential to increaseaverage antioxidant intakes, especially if consumer interest and purchasing patternsmakes the retention of antioxidants a priority for the food processing and manufacturing industries (Benbrook 2005). According to Fithriani (2009) based on the measurement parameters it was known that the antioxidant activity of fresh Caulerpa racemosa in ethyl acetate extract had the highest antioxidant activity wich shown sample conditions during processing had contribution to the activities of the antioxidant. Water-soluble antioxidant levels tend to fall when fruit juices or other processed foods are treated with water, steam blanching or other thermal processes, including pasteurization. Non-thermal processing techniques, or methods than involve lower temperatures, should be studied in more detail to determine the degreeto which they might help preserve the antioxidants that are in fresh foods prior toprocessing (Benbrook 2005). 
There are various challenges ahead for use of marine functional ingredients in daily diet. These include low consumer awareness among people about potential health benefits at grass roots level, pollution of seafood with various hazardous components as industrial waste, metals etc., sensory changes in the product with incorporation of marine food and changes in physicochemical properties of food (Khadam 2010).

\section{Toxicity}

It was found that majority of the cells died with dry extract above the level of $15 \mu \mathrm{l} / \mathrm{ml}$ due to the MT effect. Below this level, on the other hand, presence of cell death and antiproliferative effect was noted due to the toxic effects of $C$. racemosa var. cylindracea which was independent of MT. In all doses of wet extracts, similar but less prominent dose-dependent effects were observed. Below the level of $15 \mu \mathrm{l} / \mathrm{ml}$, mild toxic effect presented it self with neurite inhibition. In addition to the toxic, apoptotic and antiproliferative effects of $C$. racemosa var. cylindracea, its neurotoxic effects possessing property at low concentrations which manifesting itself by neurite inhibition was also showed. This species offers a potential for developing new drugs due to its antiproliferative, toxic and apoptotic effects. Nevertheless, its neurotoxic effect is a factor to be considered as multi functional agents especially in neuronal metabolism (Kurt 2009).

\section{CONCLUSION}

Caulerpa racemosa is one of the green seaweed that grows naturally in the waters of Indonesia, but has not been used. Caulerpa racemosa is edible or can be consumed by humans. Caulerpa racemosa have active ingredients such as antioxidant, vitamin $C$ and insoluble dietary fiber that worth to consider to be developed as a functional food. In addition to the toxic, apoptotic and antiproliferative effects of $C$. racemosa var. cylindracea. this species offers a potential for developing new drugs due to its antiproliferative, toxic and apoptotic effects. But in developing Caulerpa racemosa as functional food there are chalenges that have to solve like standardization product and impacts of food processing.

\section{REFERENCES}

Agency for Food and Drug Administration. 2001. Process Assessment Functional Food Product Standards in Drug and Food Supervisory Agency. The study Workshop Functional Food Preparation Standards; Agency for Drug and Food Control.Jakarta.

Barbier P, Guise S, Huitorel P, Amade P, Pesando D, Briand C, Peyrot V. 2001. Caulerpenyne fromCaulerpa taxifoliahas anantiproliferative activity on tumor cell line SK-N-SH and modifiesthe microtubule network. Life Sci70 : 415-429.

Bornkessel S, Bröring S, Omta SWF O, Triip HV.2013. What determines ingredient awareness of consumers? A study on ten functional food ingredients. Food Quality and Preference

Benbrook CM. 2005. Elevating Antioxidant Levels in Food through OrganicFarming and Food Processing. Organic Center State ofScience.New York .

Chew YL, Lim YY, Omar M, and Khoo, KS 2008. Antioxidant activity of three edible seaweeds from two areas in South East Asia. LWT 41; 1067-1072. 
Capiomont A, Breugnot E, Haan M and Meinesz A.2005. Phenology of a deepwater population of Caulerpa racemosa var. cylindracea in the northwestern Mediterranean Sea. Botanica Marina 48 : 80-88.

Carruthers TJB, Walker DI and Huisman JM. 1993. Culture studies on two morphological types of Caulerpa (Chlorophyta) from Perth, Western Australia, with a description of a new species. Botanica Marina 36: 589-596.

Cavas L, Baskin Y, Yurdakoc K, OlgunN. 2006. Antiproliferative and newly attributed apoptotic activities from aninvasive marine alga: Caulerpa racemosavar.cylindrace.Journal of Experimental Marine Biology and Ecology $339: 111-$ 119.

Crawford W. 2010. Fiber as Functional Food : Fiber Formulation Continue to Evolve Due to Consumer Demand. http//www.nutraceuticalsworld.com

Grajek W, Olejnik A, Sip A. 2005. Probiotics, prebiotics and antioxidants as functional foods. Acta Biochimica Polonica 52 (3): 665-67.

Fithriani D.2009. Potency antioxidan of Caulerpa racemosa in teluk Hurun. (Tesis). Bogor. Bogor Agricultural Institute.

Howlett J. 2008. Functional FoodsFrom Science to Health and Claims.: ILSI Europe concise monographs series.

Khadam SU, Prabhasankar P. 2010. Marine Foods As Functional Ingredients In Bakery And Pasta Products. Food Research International 43: 1975-1980.

Kumar M, Gupta V, Kumari P, Reddy CRK, Jha B.2011. Assessment of nutrient composition and antioxidant potential of Caulerpaceae seaweeds. Journal of Food Composition and Analysis 24 : 270-278.

Kurt,O., Ozdal-Kurt,F., Tuglu,l., Deliloglu-Gurhan,S.I., Ozturk, M. 2009. Neurotoxic effect of Caulerpa racemosa var. cylindracea by neurite inhibition on the neuroblastoma cell line Russian Journal of Marine Biology. Volume 35, Issue 4, pp 342-350.

López LI, Cofrades S, Capillas C R, Colmenero FJ.2009. Design And Nutritional Properties Of Potential Functional Frankfurters Based On Lipid Formulation, Added Seaweed And Low Salt Content. Original Research Article. Meat Science, 83( 2) : 255-262.

Misheer N, Kindness A, Jonnalagadda SB. 2006. Seaweeds along kwazulu-Natalcoast of South Africa-4: elemental uptake by edible seaweed Caulerpa racemosa(Sea grapes) and the arsenic speciation. Journal of Environmental Science and HealthA 41: 1217-123.

Mohamed S, Hashim SN, Rahman HA. 2011 .Seaweeds: A Sustainable Functional Food For Complementary And Alternative Therapy. Trends in Food Science \& Technology .

Munifah I, Suryaningrum TD, and H Krisnawang 2007. Constituent The Antioxidant Carotenoids from Marine Macro Algae. Retrieved from www.scribd.comon 8 July

Norziah MH and Ching CY. 2000. Nutritional composition of edible seaweedGracilaria changii. Food Chemistry 68 : 69-76.

Paul VJ, Fenical W, 1986. Chemical defense in tropical green algae, order Caulerpales. Mar.Ecol.Prog.Ser. 34:157-169.

Percival S.S. and TurnerRE. 2001. Applications of herbs to functional foods. In R.E.C. Wildman (Ed.). Handbook of Nutraceuticals and Functional Foods. CRC Press, Washington DC. p. 393-406.

Piazzi L, Balata D, Cecchi, Enrico and Cinelli F. 2002. Co-occurrence of Caulerpa taxifolia and C. racemosa in the Mediterranean Sea: interspecific interactions and influence on native macroalgal assemblages. Cryptogamie Algologie 24(3): 233-243.

Rasmussen RS, MorrisseyM. 2007. Marinebiotechnology for production of food ingredients. Adv Food Nutr Res 52 : 237-292.

Ruitton, S, Javel F, Culioli JM, Meinesz A, Pergent $G$ and Verlaque M. 2005. First assessment of the Caulerpa racemosa (Caulerpales, Chlorophyta) invasion along the French Mediterranean coast. Mar. Pol. Bull. 50 : $1061-1068$.

Santoso A, Yoshie Y, Suzuki T.2002. The distribution and profile of Nutrients and catechins of some Indonesian seaweeds.Fish Sci.68 (Suppl.): 1647-1648.

Santoso J. 2003. Studies on nutritional component and antioxidant activity in several Indonesian seaweeds (Disertation). Tokyo : Tokyo University of Fisheries.

Siro I, Ka'polna E, Ka'polna B, Lugasi A. 2008. Functional food. Product development, marketing and consumeracceptance-A review. Appetite 51 : 456-467. 
Verlaque M, Durandc, Huisman JM, Boudouresque F, Louis C, Parco Y.2003.On the identity and origin of the Mediterranean invasive Caulerpa racemosa (Caulerpales, Chlorophyta). Eur. J. Phycol. 38: 325-339.

Yee LW, Ikram EHK, Jalil AMM and Ismail A. 2007. Antioxidant Capacity and Phenolic Content of Selected Commercially Available Cruciferous Vegetables. J. Nutr $13: 71$.

Wijesekara I. Pangestuti R, Kim S. 2011 . Biological activities and potential health benefits of sulfated polysaccharides derived from marine algae. Carbohydrate Polymers (84) 1421.

Williams S and Grosholz E. 2002. Preliminary reports from the Caulerpa taxifolia invasion in southern California. March Ecol. Prog. Ser. 233: 307-310.

Winarti C, Nurdjanah N. (2005). Opportunity Spices And Medicinal Plants as a Source of Functional Food. Journal of Agricultural Research24 (2) :47-55. 